\title{
Comparing the Effect of Pineapple Fruit and Star Fruit to Reduce the Dental Plaque in Children Aged 10-12 Years: A Cross Sectional Study
}

\author{
Sihombing Kirana Patrolina ${ }^{*}$, Syafriani Irma, Rosma Manta, Simaremare Rosdiana Tiurlan \\ Dental Nursing Department, Medan Health Polythecnic of Ministry of Health, Medan, Indonesia \\ Email address: \\ qranasihombing@gmail.com (S. K. Patrolina) \\ ${ }^{*}$ Corresponding author \\ To cite this article: \\ Sihombing Kirana Patrolina, Syafriani Irma, Rosma Manta, Simaremare Rosdiana Tiurlan. Comparing the Effect of Pineapple Fruit and Star \\ Fruit to Reduce the Dental Plaque in Children Aged 10-12 Years: A Cross Sectional Study. International Journal of Gastroenterology. \\ Vol. 4, No. 1, 2020, pp. 11-14. doi: 10.11648/j.ijg.20200401.13
}

Received: October 7, 2019; Accepted: December 26, 2019; Published: January 16, 2020

\begin{abstract}
Tooth and mouth disease is one of the health problems that many people complain. Tooth decay in children occurs due to lack of knowledge and independence of children in maintaining oral health. As the result, it can produce more plaque. Purpose: To determine the differences between the effectiveness of chewing Pineapple and Star fruit to reduce dental plaque for children aged 10-12 years. Methods: This study used 60 peoples and divided into three groups namely the intervention group (I: chewed pineapple; II: chewed Star Fruit and III: brushes teeth as control group). Data was analyzed with non parametric Wilcoxon test and the Kruskal wallis test. Results: The plaque index before intervention were $0,73+0,18$ on group I, $0,78+0,19$ on group II, and $0,83+0,18$ on group III. After intervention plaque index were $0,47+0,18$ on group I, $0,64+$ 0,19 on group II, and $0,36+0,23$ on group III. A significant difference existed in each groups in the reduction of dental plaque index. Comparing between group there were a significant differences existed between groups but the biggest decrease diference of plaque index occurred after being treated for brushing teeth (group III). Conclusion: Treatment chewing pineapple and star fruits can decrease dental plaque but brushing teeth was more effective in reducing the dental plaque.
\end{abstract}

Keywords: Dental Plaque, Brushing Teeth, Chewing Pineapple and Star Fruit

\section{Introduction}

Dental and oral health can affect to body health [1]. According to WHO data (World Health Organization, 2013), an increase in the prevalence of dental caries in the 12 -year age group, which is $13.7 \%$ from $28.9 \%$ in 2007 to $42.6 \%$ in 2013. Oral hygiene index (OHI-s) of Indonesian is 1.46, while the national target for the OHIS index is $\leq 1.2$ [2]. According to Carranza (2012) the factors of dental and oral diseases are age, sex, socioeconomic, education, employment, fruit and vegetable consumption, physical activity, smoking, diabetes mellitus, tooth brushing, stroke, hypertension, and stress [3].

Many varieties of fruits and vegetables are safe for teeth. Fruits and vegetables contain fiber that is very effective and it can be useful as a natural tooth cleaner. In addition, chewing fruit and vegetables are also good to provide massage effects on the gums and to refresh the mouth smell [3]. Notohartojo (2016) reported that 93 percent of Indonesian peoples were still less of consuming fruits and vegetables ( $<5$ servings / day) and $95 \%$ of them have unhealthy mouth conditions. Notohartojo added foods can clean the teeth and which has function as a natural toothbrush material, of course, it will reduce tooth decay. Foods that can clean teeth include Apple, Guava, Jicama, Pineapple, and Star Fruit [4].

The results of the study of Cholid et al (2014) which used starfruit juice showed that there was a change in plaque $\mathrm{pH}$ and saliva $\mathrm{pH}$ after gargling with star fruit extract. Star fruit has an effect to decrease the $\mathrm{pH}$ of plaque because star fruit contains a lot of vitamin $\mathrm{C}$ [5]. The knowledge about the content of star fruit as a prevention of plaque is necessary to know early by children. In addition, based on the results of research Angraeni and Rahmawati (2013) showed that the 
extract of pineapple skin was effective to inhibite or to kill Streptococcus mutans bacteria because it has a Minimum Inhibitory Level at a concentration of $6.25 \%$ and Minimum Kill Rate at a concentration of $50 \%$ [6].

Bromelin enzyme from pineapple has anti-plaque with a concentration of $8.72 \%$ [7]. Beside that, another reason for choosing pineapple and star fruit in this study are due to cheaper prices, easy to find in Medan. Based on the previous research, the researchers are interested in examining how effective pineapple and star fruit compared to reduce in the number of dental plaque in children aged 10-12 years at SD Inpres 064991 Harjosari II. The purpose of this study was to determine differences of effectiveness of chewing Pineapple compare to star fruit to reduce level of dental plaque in children aged 10-12 years at SD Inpres 064991 Harjosari II.

\section{Materials and Methods}

\subsection{Study Area}

The study was carried out among primary school students of an educational institution in Medan with a total of 60 participants that selected with concecutive sampling and divided into three group by simple random sampling.

\subsection{Selection Criteria}

Inclusion criteria: Individuals with plaque - induced mild to moderate, never scalling, and accepted to participated in this study.

Group I with total 20 participant of which chewing pineapple, group II with 20 participants of which chewing star fruit, and the group III with total 20 participant which brushing teeth. Plaque index was assessed using PHP index plaque indicator for all the participants before and after intervention. Standard tooth brushing technique was thought using dental models for all.

\section{Results and Discussion}

The total dental plaque index data before and after the intervention of each group was tested for normality of data using the Shaphiro-Wilk test, as presented in table 1 below.

Table 1. Normalitis test Saphiro - Wilk.

\begin{tabular}{lll}
\hline Group & Observation & Score p \\
\hline & Initial plaque value & $0,227^{*}$ \\
Group I (Pineapple) & Final plaque value & $0,32^{*}$ \\
& Difference between initial and final plaque values & 0,04 \\
& Initial plaque value & 0,005 \\
Group II (Star Fruit) & Final plaque value & $0,089^{*}$ \\
& Difference between initial and final plaque values & 0,001 \\
Control (Brushing Teeth) & Initial plaque value & 0,001 \\
& Final plaque value & $0,078^{*}$ \\
\hline
\end{tabular}

$*=$ normal distribution $(\mathrm{p}>0,05)$.

Based on table 1 above, it was known that some data are not normally distributed. Therefore, the data of each group was tested by non-parametric tests using the Wilcoxon test and the Kruskal Wallis test. The Wilcoxon test was used to compare data before and after intervention in each group, while the Kruskal Wallis test to compare initial and final conditions.

Table 2. Initial provisions of each group

\begin{tabular}{lllll}
\hline \multirow{2}{*}{$\begin{array}{l}\text { Plaque } \\
\text { index }\end{array}$} & I & II & III & \multirow{2}{*}{ p } \\
\cline { 2 - 4 } & $\overline{\boldsymbol{X}}+$ SD & $\overline{\boldsymbol{X}}+$ SD & $\overline{\boldsymbol{X}}+$ SD & \\
\hline Before & $0,73+0,18$ & $0,78+0,19$ & $0,83+0,18$ & $0,576^{*}$ \\
\hline
\end{tabular}

$*$ : homogen $(\mathrm{p}>0,05)$.

Based on table 2 above, it is known that the average condition of plaque is based on the plaque index of each homogeneous group $(\mathrm{p}>0.05)$.

Table 3. Average Plaque Index Before and After Intervention (Test Wilcoxon).

\begin{tabular}{lllll}
\hline Indeksplak & $\mathbf{N}$ & $\overline{\boldsymbol{X}}+$ SD & $\overline{\boldsymbol{X}}+$ Difference & p-value \\
\hline I & 20 & $0,73+0,18$ & & \\
Before & 20 & $0,47+0,18$ & $0,26+0,17$ & $0,000^{*}$ \\
After & & & & \\
II & & & \\
\hline
\end{tabular}

\begin{tabular}{lllll}
\hline Indeksplak & $\mathbf{N}$ & $\overline{\boldsymbol{X}}+\mathbf{S D}$ & $\overline{\boldsymbol{X}}+$ Difference & p-value \\
\hline Before & 20 & $0,78+0,19$ & $0,13+0,11$ & $0,001^{*}$ \\
After & 20 & $0,64+0,19$ & & \\
III & & & & \\
Before & 20 & $0,83+0,18$ & $0,39+0,25$ & $0,000^{*}$ \\
After & 20 & $0,36+0,23$ & & \\
\hline
\end{tabular}

$*=$ Significant: $\mathrm{p}<0,05$.

Based on table 3 above, the PHP index average of 20 respondents in each groups were turn down. All group have $p$ value $(0.00)<\alpha(0.05)$. It means that there are significant differences in each intervention. Based on table 3 above it is known, the decrease in the value of PHP was seen more in brushing than pineapple and star fruit chewing. The differences in the average difference in the decrease in the PHP index between chewing pineapple by 0.26 , chewing star fruit by 0.13 , while brushing 0.39 . $(\mathrm{p}<0.05)$, so tooth brushing group is more effective than chewing pineapple and star fruit.

Table 4. Comparison of post intervention of each intervention group.

\begin{tabular}{lllll}
\hline Plaque & I & II & III & \multirow{2}{*}{ p-value } \\
\cline { 2 - 4 } Index & Mean + SD & Mean + SD & Mean + SD & \\
\hline After & $0,47+0,18$ & $0,64+0,19$ & $0,36+0,23$ & $0,000^{*}$ \\
$\Delta$ & $0,26+0,17$ & $0,13+0,11$ & $0,39+0,25$ & $0,000^{*}$ \\
\hline
\end{tabular}


Based on table 4 above shows that there were significant differences in the average plaque index after the intervention $(p<0.05)$. Based on the kruskal wallis test it was also found that the average difference in plaque index of the three groups was also significantly different.

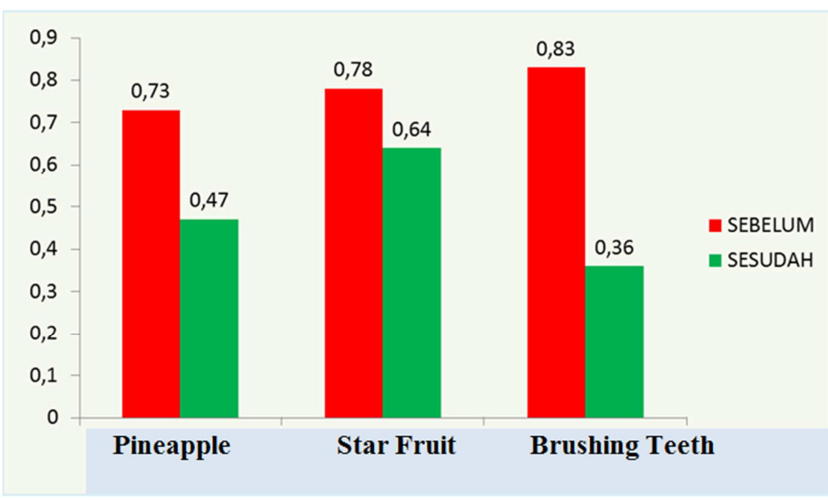

Figure 1. Graph of differences in plaque index for each group.

\section{Discussion}

Based on the results of the study there was a significant difference between decreasing the plaque index after chewing pineapple, chewing star fruit, and brushing teeth. The results showed a greater decrease in plaque index in the tooth brushing group. According to Mythri et al (2011) plaque control can be done in several ways, namely mechanical, chemical, and al natural [8]. Plaque control is performed mechanically such as brushing teeth and dental floss, including chewing on fibrous and runny food, while chemically as using mouthwash. Consumption of foods that contain fiber and water are not stimulating plaque formation, but can act as a plaque controller naturally [6].

Pineapple was a fruit that contains fiber and water. Every 100 grams of pineapple meat contains 1.4 grams of fiber and 86.37 grams of water [9]. Pineapple can be used to control dental plaque because pineapple contains bromelin enzyme which is a protein-breaking enzyme including protein in dental plaque. So it can suppress the growth of dental plaque-forming bacteria. Bromelin enzymes can break down protein bonds including glutamine-alanine which is used by bacteria as an attachment media, so that it can inhibit the attachment between bacteria and pellicles. Research said that that pineapple has an antibacterial effect both inhibiting (bacteriostatic) and killing (bactericidal) bacteria that cause caries, especially Streptococcus mutans which is found in plaques [10]. The same thing was added by Pujiastuti (1997) that the Bromelin enzyme in pineapple humps has the potential as an antiplaque agent in toothpaste through the mechanism of decomposition of the bacterial attachment media on the tooth surface. Star fruit (Averrhoacarambola) contain Epicatechin compounds as well as anti-caries because it is bactericidal. Epicatechin will inhibit the formation of plaque by inhibiting bacterial glycosylation reactions that inhibit the attachment of Streptococcus mutans to the pellicle on the tooth surface and denaturate bacterial cell proteins, there by killing the bacterial activity [7].

Fibrous foods such as pineapple and star fruit have the ability to naturally clean dental plaque. Self Cleansing occurs when fibrous food is chewed in the mouth. When chewed the fibrous food rubs the surface of the teeth which are filled with plaque [6]. Pellicle is a thin layer of glycoprotein that starts the formation of plaque. Plaque attached to the tooth surface is one of the factors causing caries. Poor tooth cleaning can cause plaque to stick and cannot be removed only by gargling with water.

Brushing teeth is one way to maintain healthy teeth. By brushing teeth, oral hygiene will also be maintained, in addition to avoiding the formation of cavities and tooth and gum disease. The habit of brushing teeth is done as one way to prevent the occurrence of dental and mouth disease. If the plaque is left for 24-48 hours, it can harden and cause gum disease and eventually cause tooth decay and other dental diseases [11]. The ability to brush teeth properly and correctly is an important factor in maintaining oral health. The success of dental and oral health is also influenced by the use of tools, the method of brushing teeth, the frequency and the right time of brushing teeth. Brushing teeth is very important to prevent plaque or debris from sticking to the tooth surface. The time or duration of tooth brushing should be as long as 2 minutes [12].

There were significant differences in the reduction in dental plaque index before and after chewing pineapple, star fruit, and brushing teeth but the biggest decrease in plaque index occurred after being treated for brushing teeth. Suggestion in for students was keep maintaining oral health by brushing teeth properly 2 times a day diligently, consuming fibrous and watery foods such as fruits and vegetables to prevent the accumulation of dental plaque. Further research needs to be done to determine the effect of gargling with pineapple and star fruit juice to decrease the dental plaque index as a controller of plaque buildup in addition to chewing fibrous and runny fruit and brushing teeth.

\section{References}

[1] Malik I, 2008. Oral health. Paper. Bandung: Padjadjaran University.

[2] RISKESDAS, 2013. Basic Health Research Ministry of Health Republic of Indonesia. Indonesian Ministry of Health's Health Research and Development Agency.

[3] Satrio, 2009. Pineapple Fruit Food and Nutrition Journal. http://www.gizi.net arranza FA \& Takei HH. in Newman et al., 2012. Rationale of Periodontal of Periodontal Treatment. Textbook of clinical periodontology. 11 th ed. pp. 387-91.

[4] Notohartojo I. T, Suratni M. A. L 2016. Brushing teeth, fruit and vegetable consumption, physical activity, Diabetes Mellitus with Periodontal Dental Networks in Indonesia in 2013. Research and Development Center for Health Resources and Services, Vol. 03 No. 1, pp. 25-30. 
[5] Cholid B, Santoso O, Rochmah Y, 2014. Effect of sweet starfruit juice mouth rinse on changes in plaque $\mathrm{pH}$ and salivary $\mathrm{pH}$. Dental intellectual media journal medal, Vol. 2 1 ed.

[6] Huda HH, Aditya G, Praptiningsih 2015. Effectiveness of Fuji apple (Pyrusmalus) type consumption on dental plaque score and salivary $\mathrm{pH}$. J.

[7] Pujiastuti, Peni, 1997. Biocompatibility Test of Pineapple Cob Extract Extract as a Mouthwash. Thesis, Postgraduate, Airlangga University, Surabaya.

[8] Mythri H, Ananda SR, Prashant GM, Subba Reddy VV, Chandu GN, 2011. The efficacy of antiseptic mouth rinses in comparison with dental floss in controlling interproximal gingivitis. J IntSoc Prevent Communit Dent; 1 (1): 31-5.
[9] Sidi NC, Widowati E, Nursiwi, 2014. A. Journal of Food Technology Applications. Surakarta: Indonesian Food Technologists. 3: 122.

[10] Rakhmanda AP, 2008. Comparison of the antibacterial effects of pineapple juice (Ananascomosus L. Merr) at various concentrations of Streptococcus mutans [Scientific writing]. Semarang: Diponegoro University.

[11] Oki N, Eram TP, Bambang W. 2012. Comparison of power point media and flip charts in improving dental and oral health knowledge. Unnes Journal of Public Health. Vol. 1 No. 12. h. 32-35.

[12] Ilyas Muhammad, Indah Nisita Putri, 2012. The effect of counseling on a tooth brushing demonstration method on decreasing the dental plaque index in elementary school students, Dentofacial, Vol. 11, No. 2. 